\title{
PENGARUH STRUKTUR MODAL TERHADAP PROFITABILITAS KOPERASI PEGAWAI REPUBLIK INDONESIA (KPRI)
}

\author{
Nissya Endah Ismawati, Agung Winarno \\ Jurusan Manajemen, Universitas Negeri Malang, Malang, Indonesia \\ agung.winarno.fe@um.ac.id
}

\begin{abstract}
This research aimed at examining the effects of debt to asset ratio (DAR) and debt to equity ratio (DER) towards ROA. This study used an associative and causality qualitative approach. The objects of this research were 62 employee's savings and loan cooperatives of Republic of Indonesia (KPRI) in Malang City. Data analysis used was multiple regression analysis. The research result showed that ROA tended to be descending whilst it was still categorized efficient in earning profits. DAR tended to be descending whilst it was still categorized efficient in debt usage. Contrastly, DER tended to be ascending although it was still categorized efficient in det usage. DARE has a significantly negative effects towards ROA while DER has no effects towards ROA.
\end{abstract}

Keyword: Debt to Asset Ratio (DAR), Debt to Equity Ratio (DER), and Return on Asset (ROA)

\begin{abstract}
Abstrak: Penelitian ini bertujuan untuk menguji hubungan antara struktur modal dengan profitabilitas koperasi. Struktur modal dalam penelitian ini diukur menggunakan variabel debt to asset ratio (DAR) dan debt to equity ratio (DER), sedangkan untuk profitabilitas diukur menggunakan varibabel ROA. Penelitian ini menggunakan pendekatan kuantitatif asosiatif kausalitas dengan analisa regresi berganda. Objek penelitian adalah 62 Koperasi Pegawai Republik Indonesia (KPRI) di Kota Malang. Hasil penelitian ini menunjukkan bahwa, (1). ROA cenderung menurun namun masih dalam kategori efisien dalam menghasilkan laba, (2). DAR cenderung menurun namun masih dalam kategori efisien dalam penggunaan utang, (3). DER cenderung meningkat namun masih dalam kategori efisien dalam penggunaan utang, (4). DAR berpengaruh negatif terhadap ROA, (5). DER tidak berpengaruh terhadap ROA.
\end{abstract}

Kata kunci: Debt to Asset Ratio (DAR), Debt to Equity Ratio (DER), and Return on Asset (ROA)

Krisis ekonomi yang melanda Indonesia pada tahun 1998 telah menimbulkan permasalahan ekonomi, salah satunya adalah menimbulkan kredit macet sebesar 30 persen dan pertumbuhan ekonomi minus 13 persen. Akan tetapi, ditengah badai krisis ekonomi tahun 1998 koperasi muncul sebagai penyelamat dari perekonomian Indonesia. Tercatat, dalam kurun waktu lima tahun pertumbuhan ekonomi dapat mencapai empat persen (Beritalima, 2016). Adanya krisis di tahun 1998 menunjukkan bahwa koperasi mampu menjadi penyangga ekonomi nasional dan anti resesi. Hal ini mendorong pemerintah Indonesia untuk terus meningkatkan dan memajukan sektor koperasi serta menyiapkan koperasi sebagai lembaga permodalan bagi masyarakat.

Berdasarkan data BPS Jatim Tahun 2015, kontribusi Koperasi dan UMKM terhadap Produk Domestik Regional Bruto
(PDRB) di Jawa Timur mencapai 54,98\% dari total PDRB Jatim yakni sebesar Rp. 1.689 triliun. Selain itu, Koperasi dan UMKM juga mampu menyerap tenaga kerja sekitar 92 persen (BPS Jawa Timur, 2015). Salah satu koperasi yang memberikan dampak positif terhadap pertumbuhan perekonomian masyarakat khususnya masyarakat dilingkungan instansi pemerintah adalah KPRI. KPRI merupakan lembaga keuangan bukan bank yang bergerak di bidang penyimpanan dana (tabungan) dan penyaluran dana (pinjaman) yang diharapkan mampu memenuhi kebutuhan modal anggota. Dalam proses menghasilkaan keuntungan maka dapat dilihat dari kinerja keuangan KPRI tersebut terutama pada kondisi struktur modalnya.

Modigliani \& Miller dalam Sheikh (2013:355) mengemukakan bahwa perusahaan harus menggunakan utang maksimum dalam struktur modal karena dapat 
mengurangi pembayaran bunga pajak. Dengan demikian, penggunaan utang maksimum memiliki dampak positif terhadap kinerja keuangan perusahaan. Selain itu, Jermias (2008:72) menunjukkan bahwa pendanaan utang tidak hanya menawarkan keuntungan dari pajak untuk membayar beban-beban, tetapi juga membuat meningkatnya efisiensi pembayaran utang jatuh tempo. Alternatifnya, Simerly \& Li (2000:32) berpendapat bahwa penggunaan utang untuk membiayai struktur modal perusahaan dapat membuat beberapa perusahaan memiliki orientasi pada utang jangka pendek.

Rasio profitabilitas merupakan rasio untuk menunjukkan seberapa efisien suatu perusahaan koperasi atau seberapa besar kemampuan koperasi memberikan manfaat atas modal yang diinvestasikan anggotanya (Hendar, 2010:202). Mengukur kinerja keuangan koperasi dapat melalui Return on Asset (ROA) yang menunjukkan kemampuan perusahaan dalam menghasilkan laba yang bersumber dari total aset yang dimilikinya.

Selain itu rasio yang digunakan untuk mengukur struktur modal koperasi adalah Debt to Asset Ratio (DAR) dan Debt to Equity Ratio (DER). Semakin tinggi utang maka semakin tidak baik, karena semakin tinggi pula risiko keuangan yang ditanggung oleh perusahaan (Halim, 2015:216). Debt to Asset Ratio (DAR) menunjukkan kemampuan koperasi dalam menjamin utang berdasarkan aset-aset yang dimiliki koperasi. Semakin tinggi rasio ini maka pendanaan dengan utang akan menyulitkan perusahaan untuk memperoleh tambahan pinjaman karena di khawatirkan perusahaan tidak mampu menutupi utang-utangnya dengan aktiva yang dimilikinya. Rasio yang tinggi juga menunjukkan proporsi modal sendiri yang rendah untuk membiayai aktiva (Sartono, 2010:121).

Sedangkan Debt to Equity Ratio (DER) menunjukkan rasio utang atas modal sendiri digunakan untuk mengukur kemampuan modal sendiri yang dimiliki perusahaan koperasi dalam membayar seluruh utangutangnya (Hendar, 2010:200). Semakin tinggi rasio ini berarti koperasi mempunyai kemampuan meminjam lebih kecil, pemberi pinjaman memandang koperasi telah tergadaikan. Begitu pula sebaliknya apabila rasio utang rendah maka koperasi memiliki kemampuan meminjam lebih tinggi.

Berdasarkan uraian di atas, maka penting untuk melihat bagaimana mengukur kinerja koperasi melalui hubungan antara struktur modal kerja dengan profitabilitas. Oleh karena itu, penelitian ini bertujuan untuk mengukur kinerja keuangan KPRI melalui hubungan antara Debt to Asset Ratio (DAR) dan Debt to Equity Ratio (DER) terhadap Return on Asset (ROA) pada 16 KPRI yang aktif di kota Malang.

\section{METODE}

Penelitian ini menggunakan pendekatan kuantitatif asosiatif kausalitas yang menguji hubungan antara variabel independent dan variabel dependent. Populasi dalam penelitian ini adalah seluruh Koperasi Pegawai Republik Indonesia di Kota Malang yang masih aktif hingga tahun 2015 yang berjumlah 72 untuk KPRI dan terdapat 62 koperasi yang rutin melakukan RAT hingga tahun 2015. Teknik sampling yang digunakan dalam penelitian ini adalah purposive sampling. Berdasarkan kreteria yang sudah ditetapkan maka sampel dalam penelitian ini sebanyak 16 KPRI di kota Malang. Pengumpulan data yang digunakan dalam penelitian ini menggunakan teknik dokumentasi yaitu dengan mencatat atau menyalin data yang telah diterbitkan oleh koperasi. Analisis data menggunakan analisis deskriptif, Uji Asumsi Klasik, Analisis Regresi Berganda, dan uji hipotesis.

\section{HASIL \\ Return on Asset (ROA)}

Kondisi Return on Assets (ROA) KPRI menunjukkan trend menurun. Hal ini dapat disebabkan pertumbuhan aset yang semakin bertambah setiap tahun dan tidak dimbangi dengan peningkatan SHU sebelum pajak. Perhitungan ROA menunjukkan rata-rata ROA tertinggi tahun 2013-2015 adalah KPRI Aneka Guna yakni sebesar $13.7 \%$ hal ini dapat dikarenakan masa kerja KPRI sudah cukup lama sehingga KPRI mampu menghasilkan laba yang tinggi. Sedangkan rata-rata ROA terendah dimiliki oleh KPRI Gajayana yaitu sebesar $1.7 \%$ hal ini dapat dikarenakan hanya berfokus dalam mengembangkan pengelolaan asetnya saja dan tidak berorientasi untuk 
menghasilkan laba dari total aset yang dimilikinya ini dapat terlihat dari nilai aset yang semakin bertambah setiap tahunnya. Pada tahun 2013 rata-rata ROA KPRI di Kota Malang adalah sebesar 7.5\%, sedangkan pada tahun 2014 rata-rata ROA mengalami penurunan menjadi sebesar $6.7 \%$, dan di tahun 2015 rata-rata ROA mengalami kenaikan sebesar $7.4 \%$. Sehingga dapat disimpulkan bahwa rata-rata ROA KPRI di Kota Malang mengalami penurunan dari tahun 2013-2015.

\section{Debt to Asset Ratio (DAR)}

Kondisi debt to assets ratio (DAR) KPRI menunjukkan trend menurun. Hal ini dapat dikarenakan kinerja koperasi semakin meningkat yang berarti semakin menurunnya porsi utang dalam pendanaan aktiva. Dengan demikian kenaikan total utang yang lebih besar daripada kenaikan total aset yang menyebabkan menurunnya kemampuan koperasi untuk membayar utangnya. Perhitungan DAR menunjukkan rata-rata DAR tertinggi tahun 2013-2015 adalah KPRI UB yakni sebesar $75.3 \%$ hal ini dapat dikarenakan utang yang dimiliki koperasi sangat tinggi sedangkan aset yang dimilikinya tidak dapat menutup utangnya. Sedangkan rata-rata DAR terendah dimiliki oleh KPRI Bumi Karya Setia yaitu sebesar $6.3 \%$ dikarenakan utang yang dimiliki koperasi sangatlah rendah sehingga koperasi tidak perlu menggunakan nilai asetnya untuk membiayai utang koperasi. Pada tahun 2013 rata-rata DAR KPRI di Kota Malang adalah sebesar $41.4 \%$, sedangkan pada tahun 2014 rata-rata DAR mengalami kenaikan menjadi sebesar $42.9 \%$, dan di tahun 2015 rata-rata DAR mengalami penurunan menjadi $39.8 \%$. Sehingga dapat disimpulkan bahwa rata-rata DAR KPRI di Kota Malang mengalami penurunan dari tahun 2013-2015.

\section{Debt to Equity Ratio (DER)}

Kondisi debt to equity ratio (DER) KPRI menunjukkan trend meningkat. Meningkatnya DER disebabkan karena kebijakan koperasi lebih memilih menambah penggunaan utang daripada menggunakan dana internal untuk mendanai usahanya. Perhitungan DER menunjukkan rata-rata DER tertinggi pada tahun 2013-2015 adalah
KPRI Gajayana yakni sebesar $189.7 \%$ hal ini dikarenakan utang yang dimiliki koperasi tidak dapat ditutup dengan modal sendiri yang dimiliki koperasi. Sedangkan rata-rata DER terendah dimiliki oleh KPRI Kokar yaitu sebesar $14.3 \%$ hal ini dikarenakan modal sendiri yang dimiliki koperasi lebih besar daripada utang, sehingga koperasi mampu menutup utang yang dimilikinya berdasarkan modal sendiri yang dimiliki koperasi. Pada tahun 2013 rata-rata DER KPRI di Kota Malang adalah sebesar $73.9 \%$, sedangkan pada tahun 2014 rata-rata DER mengalami kenaikan yaitu sebesar $79.3 \%$, dan di tahun 2015 rata-rata DER mengalami kenaikan yaitu sebesar $82.6 \%$. Sehingga dapat disimpulkan bahwa rata-rata DER KPRI di Kota Malang mengalami peningkatan secara terus menerus dari tahun 2013-2015.

\section{Uji hipotesa}

Untuk mengetahui pengaruh DAR dan DER terhadap ROA maka pada tabel 1 ditunjukkan hasil perhitungan regresi sebagai berikut.

\section{Tabel 1. Hasil Analisis Regresi Berganda}

\begin{tabular}{|c|c|c|c|c|c|}
\hline \multirow[t]{2}{*}{ Model } & \multicolumn{2}{|c|}{$\begin{array}{c}\text { Unstandardized } \\
\text { Coefficients }\end{array}$} & $\begin{array}{c}\text { Standar } \\
\text { dized }\end{array}$ & \multirow[t]{2}{*}{$\mathrm{t}$} & \multirow[t]{2}{*}{ Sig. } \\
\hline & B & $\begin{array}{l}\text { Std. } \\
\text { Error }\end{array}$ & Beta & & \\
\hline $\begin{array}{c}\text { (Consta } \\
\text { nt) }\end{array}$ & 12.411 & .783 & & 15.844 & .000 \\
\hline DAR & -.094 & .035 & -.551 & -2.686 & .010 \\
\hline DER & -.017 & .014 & -.238 & -1.161 & .252 \\
\hline
\end{tabular}

Sumber: Pengolahan data

Berdasarkan Tabel 4.1 dapat diperoleh persamaan regresi linear berganda sebagai berikut.

$$
\mathrm{Y}=12.411-0.094\left(\mathrm{X}_{1}\right)-0.017\left(\mathrm{X}_{2}\right)+\mathrm{e}
$$

\section{a. Pengaruh DAR terhadap ROA}

Uji statistik $t$ menunjukkan nilai signifikansi sebesar $0.010 \leq 0.05$ dengan demikian H0 ditolak sehingga DAR berpengaruh negatif signifikan terhadap ROA. Sedangkan nilai koefisien beta adalah sebesar -0.094 yang berarti apabila DAR mengalami kenaikan $1 \%$ maka tingkat ROA akan mengalami penurunan sebesar $0.094 \%$. 
b. Pengaruh DER terhadap ROA

Uji statistik $t$ menunjukkan nilai signifikansi sebesar $0.252>0.05$ dengan demikian H0 diterima sehingga DER tidak berpengaruh signifikan terhadap ROA. Hal ini berarti perubahan DER tidak akan mengubah besar ROA.

\section{PEMBAHASAN}

\section{Pengaruh Debt to Asset Ratio terhadap Return on Asset}

Berdasarkan hasil penelitian diketahui bahwa Debt to Asset Ratio berpengaruh negatif signifikan terhadap Return on Asset. Hasil tersebut menunjukkan bahwa semakin menurunnya DAR pada koperasi akan meningkatkan ROA koperasi tersebut. Hal ini berarti semakin rendah tingkat utang suatu koperasi maka kinerja keuangan koperasi yang diukur dengan ROA semakin meningkat, begitu pula sebaliknya. Koperasi akan menjadi kurang baik apabila menggunakan utang semakin besar. Dengan sumber dana yang lebih besar, keuntungan dapat meningkat namun diikuti pula dengan peningkatan risiko yang lebih besar dari peningkatan keuntungan. Semakin rendah rasio utang menunjukkan bahwa hanya sebagian kecil aset perusahaan yang dibiayai dengan utang. Begitu juga sebaliknya, semakin besar rasio ini berarti semakin besar pula leverage perusahaan (Sartono, 2010:54).

Koperasi tidak dapat terus menerus menopang usahanya melalui pendanaan internalnya saja. Akan tetapi koperasi juga tidak dapat sepenuhnya membiayai seluruh aktivitasnya menggunakan pendanaan eksternal berupa utang. Kasmir (2011:156) menyatakan bahwa apabila pendanaan dengan utang semakin banyak maka akan sulit bagi perusahaan koperasi untuk memperoleh dana ekstrnal. Koperasi perlu mendasarkan keputusan pendanaan pada struktur modal yang optimal. Dimana terdapat keseimbangan manfaat dalam penggunaan utang serta risiko dari manfaat tersebut.

Pada tahun 2013-2015 kondisi DAR pada KPRI Kota Malang terus mengalami penurunan setiap tahunnya. Kondisi ini menunjukkan tingkat utang yang menurun, akan tetapi pengelolaan hasil aktiva tidak dapat menutup utang dengan baik. Karena hasil pengelolaan aktiva hanya akan menambah laba koperasi saja. Kondisi ini menjadi alasan menurunnya DAR dapat meningkatkan ROA koperasi.

Hasil penelitian ini sejalan dengan pecking order theory, Myers menyatakan bahwa penggunaan utang akan meningkatkan nilai koperasi namun hanya pada titik tertentu setelah titik tersebut, penggunaan utang justru akan menurunkan nilai koperasi karena kenaikan keuntungan atau laba dari penggunaan utang tidak sebanding dengan biaya bankruptcy dan agency problem.

\section{Pengaruh Debt to Equity Ratio terhadap Return on Asset}

Debt to Equity Ratio tidak terdapat pengaruh signifikan terhadap Return on Asset. Hasil tersebut berarti adanya kenaikan maupun penurunan dari DER tidak akan mempengaruhi kondisi ROA koperasi. Dari tahun 2013-2015 penggunaan utang yang dilakukan koperasi terus meningkat, akan tetapi peningkatan ini tidak berdampak pada kenaikan ROA koperasi. Hal ini tidak sejalan dengan pernyataan Sartono (2010:114) yang menyatakan bahwa semakin besar DER maka semakin besar pula ROA koperasi.

Tidak berpengaruhnya DER terhadap ROA koperasi juga dikarenakan koperasi lebih menggunakan utang daripada modal sendiri untuk membiayai kegiatan operasionalnya. Proporsi modal sendiri koperasi lebih kecil daripada proporsi utang pada beberapa KPRI. Penggunaan modal sendiri pada kegiatan operasional koperasi akan memberikan dampak yang berbeda pada perusahaan yang lebih banyak menggunakan utang dalam kegiatan operasionalnya. Ini dikarenakan penggunaan utang akan menimbulkan beban bunga, sehingga akan mengurangi laba bersih koperasi dikarenakan laba operasi digunakan untuk menutupi beban bunga dari kebijakan utang yang diambil koperasi.

Menurut pecking order theory terdapat pengaruh negatif antara profitabilitas dan penggunaan utang, selain itu ketika koperasi menggunakan utang harus berdasarkan kebutuhan pendanaannya, hal ini akan menurunkan presentase penggunaan utang dalam struktur modal koperasi karena koperasi mampu menghasilkan laba (Sudana, 2011:155). Dengan demikian penelitian ini 
tidak mendukung pecking order theory karena peningkatan DER berasal dari utang yang meningkat akan tetapi modal sendiri yang di miliki koperasi berada pada kondisi konstan. Hal tersebut tentu dapat mengakibatkan peningkatan risiko pada modal sendiri yang dimiliki koperasi karena koperasi dirasa tidak mampu menutup utang yang dimilikinya atau dengan kata lain koperasi menjadi kurang produktif dengan peningkatan utang yang tinggi. Selain itu DER yang tinggi dirasa tidak aman oleh para kreditur untuk memberikan pinjaman kepada koperasi, dengan terhambatnya pinjaman maka akan mengganggu kegiatan operasional koperasi sehari-hari, tentu hal itu juga kan berpengaruh pada laba yang akan di terima oleh koperasi yang menurun pada titik tertentu nantinya.

Tidak terdapatnya pengaruh DER terhadap ROA juga dikarenakan peningkatan rata-rata DER sehingga hal tersebut mengindikasikan bahwa koperasi lebih memilih pendanaan dengan menggunakan utang daripada dengan menggunakan modal sendiri. Modigliani dan Miller dalam Sukardi \& Herdinata (2009) menyatakan penggunaan utang akan mengurangi laba yang terkena pajak sehingga dipandang lebih menguntungkan koperasi karena terdapat penghematan pajak. Akan tetapi hasil penelitian ini tidak mendukung teori MM bahwa perusahaan koperasi dengan menggunakan utang lebih baik daripada yang tidak menggunakan utang.

\section{KESIMPULAN DAN SARAN Kesimpulan}

Berdasarkan hasil dan pembahasan di atas, dapat disimpulkan bahwa (1). Debt to Asset Ratio (DAR) berpengaruh negatif terhadap ROA KPRI. Hasil tersebut menunjukkan bahwa semakin menurunnya DAR pada koperasi akan meningkatkan ROA koperasi tersebut. (2). Debt to Equity Ratio (DER) tidak berpengaruh terhadap ROA. Hasil tersebut menunjukkan bahwa kenaikan maupun penurunan dari DER tidak akan mempengaruhi kondisi ROA koperasi.

\section{Saran}

Berdasarkan pembahasan di atas maka koperasi harus memperhatikan variabel Debt to Asset Ratio (DAR) untuk mengelola profitabilitas koperasi. Hal ini karena tinggi rendahnya profitabilitas koperasi sangat dipengaruhi oleh DAR koperasi yang bersangkutan. Sedangkan untuk peneliti selanjutnya dapat menambahkan variabel diluar struktur modal untuk mengetahui kinerja profitabilitas koperasi antara lain perputaran kas, perputaran piutang dan perputaran modal kerja.

\section{DAFTAR RUJUKAN}

Badan Pusat Statistik Jawa Timur. 2015. Perkembangan Kelembagaan dan Usaha Koperasi. (Online), (www.jatim.bps.go.id), diakses 7 Oktober 2016.

Beritalima. 10 September 2016. Pakde Karwo: Negara Harus Berpihak Pada Koperasi dan UMKM, (Online), (www.beritalima.com), diakses 8 Oktober 2016.

Dokumentasi Laporan Keuangan RAT KPRI di Kota Malang periode 2013-2015.

Halim, A. 2015. Manajemen Keuangan Bisnis Konsep dan Aplikasinya. Jakarta : Mitra Wacana Media.

Hendar. 2010. Manajemen Perusahaan Koperasi. Jarata : Erlangga.

Jermias, J. 2008. The Relative Influence of Competitive Intensity and Bussiness Strategy on The Relationship Between Financial Leverage and Performance. The British Accounting Review, (Online), 40: 71-86, (www.sciencedirect.com), diakses 7 Oktober 2016.

Kasmir. 2011. Analisis Laporan Keuangan. Jakarta: PT Rajagrafindo Persada.

Sartono, Agus. 2010. Manajemen Keuangan Teori dan Aplikasi Edisi 4. Yogyakarta: BPFE.

Sheikh, A. 2013. The Impact of Capital Structure on Performance: An Empirical Study of Non-Financial Listed Firms in Pakistan. International Journal of Commerce and Management, (Online), 23 (4): 354-368, (www.emeraldinsight.com), diakses 28 September 2016.

Simerly, R.L \& Li, M. 2000. Environmental Dynamism, Capital Structure and Performance: A Theoretical Integration and An Empirical Test. Strategic 
34 | EKOBIS - Ekonomi Bisnis Vol. 23 No. 1 | Mei 2018 | Halaman 29-34

Management Journal, (Online), 21: 31-

49, (www.onelibrary.wiley.com), diakses 8 Oktober 2016.

Sudana, Made I. 2011. Manajemen Keuangan Perusahaan (Teori dan Praktik). Jakarta: Erlangga.

Sukardi, D \& Herdinata, C. 2009. Manajemen Keuangan Based on Empirical Research. Yogyakarta: Graha Ilmu.

Undang-Undang Republik Indonesia Nomor 17 Tahun 2012 Tentang Perkoperasian. (Online). (www.depkop.go.id), diakses 07 Maret 2017. 